\title{
Cytokines in asthma
}

\author{
J.C. Kips
}

Cytokines in asthma. J.C. Kips. C) ERS Journals Ltd 2001.

ABSTRACT: The airway inflammation underlying asthma is regulated by a network of mutually interacting cytokines. The exact functional role of each individual cytokine in the pathogenesis of the disease remains to be fully established.

Type 2 T-helper cells are currently considered to play a crucial role in this process. In vivo animal data suggest a sequential involvement of interleukin (IL)-4 and IL-5 in the induction of allergen-induced airway changes. The potential role of other type 2 T-helper cell-like cytokines in asthma is increasingly being recognized. In particular, IL-4 and -13 display a large degree of redundancy. Whereas IL-4 seems to be crucial in the primary allergen sensitization process, IL-13 might be more important during secondary exposure to aerosolized allergen. Animal models also indicate that T-cellderived cytokine production, rather than eosinophil influx or immunoglobulin-E synthesis, is causally related to altered airway behaviour.

An important aspect when evaluating the functional role of cytokines in a complex disease such as asthma is the interaction with other cytokines in the microenvironment. Increased expression of pro-inflammatory cytokines such as tumour necrosis factor- $\alpha$ can further enhance the inflammatory process, and is increasingly linked to disease severity. In addition, decreased expression of immunoregulatory cytokines, including interleukin-12, interleukin-18 or interferon gamma could also strengthen the type 2 T-helper cell-driven inflammatory process.

Eur Respir J 2001; 18: Suppl. 34, 24s-33s.
Correspondence: J.C. Kips Dept Respiratory Diseases Ghent University Hospital De Pintelaan 185

B-9000 Ghen

Belgium

Fax: 3292402341

Keywords: Asthma

cytokine

interleukin

pathogenesis

tumour necrosis factor- $\alpha$

Received: March 262001

Accepted June 182001
Asthma is currently considered and defined as a chronic inflammatory disorder of the airway mucosa [1]. The pathogenesis of the disease process can be regarded as a two-step phenomenon. The first step consists of sensitization to an aeroallergen, which involves the preferential development of antigenspecific T-helper (Th) cells type 2. The second step, which does not occur in all atopic individuals, consists of targeting the Th2-driven allergic inflammation to the lower airways. This inflammatory process is orchestrated and regulated by a complex network of mutually interacting cytokines and growth factors, secreted not only by a range of inflammatory cells but also from structural tissue components, including epithelial cells, fibroblasts and smooth muscle cells. The resulting inflammation of the airway mucosa shows signs of an acute as well as a more chronic type of inflammation [2]. This latter phenomenon causes remodelling of the airway wall, resulting in a number of structural alterations. Biopsy studies in asthma illustrate increased expression of an ever-increasing number of cytokines. Overall, these can be grouped as Th2-like cytokines, such as interleukin (IL)-4, -5, -9 and -13, pro-inflammatory cytokines including tumour necrosis factor- $\alpha$ (TNF- $\alpha)$ and IL- $1 \beta$, chemokines such as regulated on activation, normal $\mathrm{T}$-cell expressed and secreted (RANTES), eotaxin and monocyte chemotactic protein(MCP)-1, and growth factors, including transforming growth factor- $\beta$ and epidermal growth factor (fig. 1).

Although insight into the pathophysiology of asthma has increased substantially over recent years, a number of issues remain to be further clarified. These include a better understanding of the exact functional role of each cytokine in the sensitization process and in the complex relationship between inflammation, remodelling and altered airway behaviour. Providing proof of the functional importance of a given cytokine in asthma usually follows Koch's postulates. This means assessing whether expression of a given cytokine is altered in asthmatic airways, whether exogenous administration of the cytokine mimics certain features of asthma and, finally, whether antagonizing the endogenously released cytokine blocks allergen-induced changes or offers clinical efficacy in ongoing asthma. The data currently available in this respect rely largely on a combination of descriptive human data and interventional studies conducted in in vivo animal models. It can be anticipated that further insight into the functional role of cytokines will result in novel therapeutic perspectives. For some cytokines, specific inhibitors are currently being developed for human use. It will be interesting to see how they lead to better understanding of the disease process in the individual patient and allow for fine-tuning of treatment regimens. This review, rather than attempting to cover all 
Virus

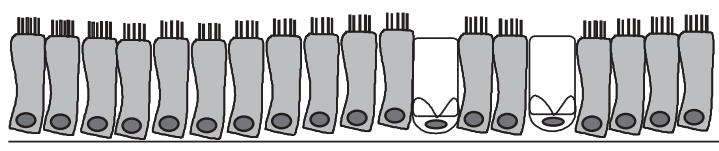

Antigen

口
$\mathrm{NO}_{2}$

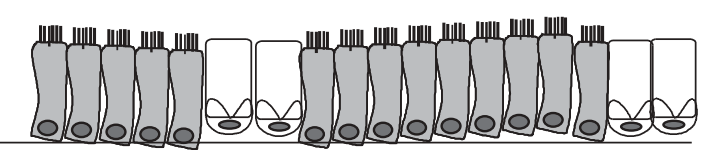

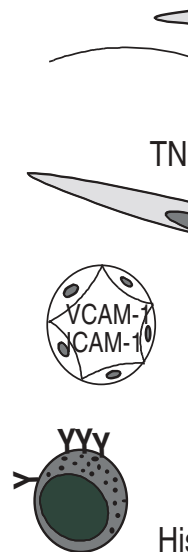

His

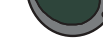

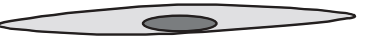

EGF

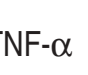

$N F-\alpha$

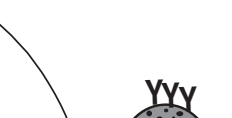

HT

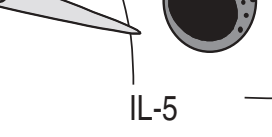

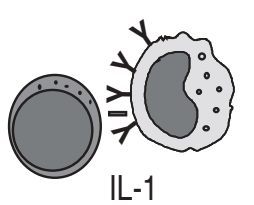

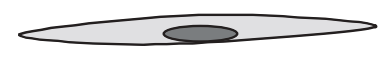

GM-CSF

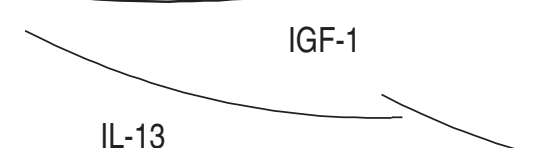

IL-13

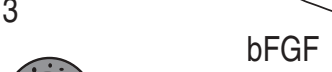

(1)
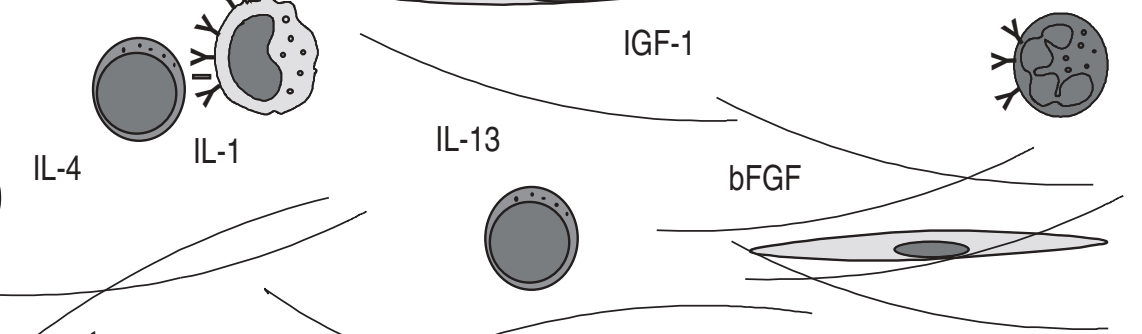

$F-\alpha$

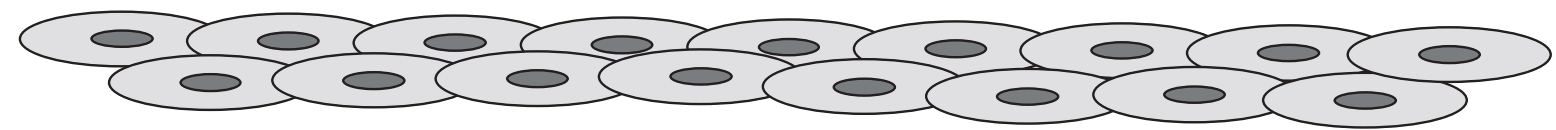

Fig. 1.-Airway inflammation and remodelling in asthma. Schematic section through airway wall. EGF: epidermal growth factor; GM-CSF: granulocyte-macrophage colony-stimulating factor; TNF- $\alpha$ : tumour necrosis- $\alpha$ factor; IL: interleukin; bFGF: basic fibroblast growth factor; VCAM-1: vascular cell adhesion molecule-1; ICAM-1: intercellular adhesion molecule-1; MCP-1: monocyte chemotactic protein-1; His: histamine; LT: leukotriene; TFG- $\beta$ : transforming growth factor- $\beta$; PDGF: platelet-derived growth factor.

cytokines, focuses on a few that have been highlighted as potential therapeutic targets.

\section{Type 2 T-helper cell-like cytokines}

Within the range of cytokines produced by Th2, IL-4 and -5 have received considerable interest to date.

\section{Interleukin-4}

IL-4 demonstrates a broad range of biological activities. In general terms, it can be described as the main cytokine involved in the pathogenesis of allergic responses, at the same time downregulating acute inflammatory changes [3]. Additional effects that seem of particular importance for asthma include stimulation of mucus-producing cells and fibroblasts, thus also implicating IL-4 in the pathogenesis of airway remodelling [4-6]. Inhalation of recombinant human IL-4 has been shown to induce airway eosinophilia and to cause some degree of bronchial hyperresponsiveness in atopic asthmatics [7]. In addition, bronchial biopsy studies have confirmed increased expression of IL-4 at both the messenger ribonucleic acid (mRNA) and protein level in the airway mucosa of atopic and even nonatopic asthmatics compared to nonasthmatic controls [8-10]. IL-4 exerts its biological activities through binding to the IL-4 receptor (IL-4R), which is expressed on the surface of diverse cell types. The IL-4R is a heterodimer, consisting of the IL-4-binding IL$4 \mathrm{R} \alpha$ chain and a second chain, which is either the $\gamma \mathrm{c}$ chain (shared in common with the receptor for IL-2, $-7,-9$ and -15$)$ or the IL-13R $\alpha$ chain $[11,12]$. Increased expression of the IL-4R $\alpha$ chain in the epithelium and subepithelium of asthmatic airways has been reported [13]. Polymorphisms of the IL-4 and IL-4R $\alpha$ genes have also been related to asthma severity. In particular, the IL-4-589T allele, which has been associated with increased IL-4 gene expression, has been found to be a risk factor for life-threatening asthma [14].

The functional role of IL-4 has been evaluated in a number of in vivo animal models. The present author has developed a model of allergen (ovalbumin)induced airway changes in $\mathrm{C} 57 \mathrm{~B} 1 / 6$ mice. In this model, IL-4 was shown to be essential for the development of ovalbumin-induced eosinophil influx into the airways, immunoglobulin-E ( $\mathrm{IgE}$ ) production and the increase in airway responsiveness [15]. More recent studies show very similar results in mice deficient in signal transducer and activator of transcription (Stat)-6, which is considered central to the signalling pathway for mediating the biological responses to IL-4 [16, 17]. In the present authors' model, mast cell-deficient mice still develop airway eosinophilia in response to ovalbumin exposure, whereas major histocompatibility complex class II-deficient mice, lacking functionally active T-cells, do not [18]. This indicates, as has been confirmed by others, that the crucial role of IL-4 lies in its effect on Th2 development, rather than on the induction of 
IgE synthesis and subsequent mast cell degranulation [19]. This is in line with a number of other investigations. TAKEDA et al. [20], for example, have shown that mast cell-deficient mice and their wild-type littermates develop a comparable increase in both airway eosinophil number and bronchial responsiveness when sensitized and exposed to ovalbumin. Similarly, Menlhop et al. [21] reported that, in $\operatorname{IgE}^{-/-}$mice, sensitization and exposure to Aspergillus extract induced a comparable degree of airway inflammation and methacholine responsiveness to that found in wild-type animals. Finally, using B-cell-deficient mice, it was shown that the absence of any immunoglobulin production does not prevent development of allergic airway inflammation [22, 23]. Overall, these observations indicate that the IgE/mast cell axis does not play a major role in the induction of allergen-induced airway inflammation and bronchial hyperresponsiveness. Importantly, these experiments do not permit the exclusion of a possible modulatory role of $\operatorname{IgE}$ by enhancing T-/B-cell interaction [24, 25].

At the same time, what clearly emerges is the central role of T-cells in these models. Further studies, using different approaches, including pretreatment with anti-CD4 antibodies and passive transfer of cells, confirm the functional importance of CD4 cells and, more specifically, Th2 [26-30]. Importantly, although exogenous administration or lung-specific overexpression of IL-4 in transgenic mice causes epithelial hypertrophy and some degree of peribronchial inflammatory change, this is not accompanied by increased airway hyperresponsiveness, suggesting that IL-4 in itself is insufficient to induce all the changes characteristic of asthma, and that other Th2-derived cytokines are also involved [31, 32]. An obvious possibility in this respect is IL-5.

\section{Interleukin-5}

It barely needs repeating that the eosinophil is considered a key effector cell in the pathogenesis of allergic inflammation. Despite possible redundancy with other cytokines, such as IL-3 and granulocytemacrophage colony-stimulating factor (GMCSF), IL5 seems to be the primary cytokine involved in vivo in the production, differentiation, maturation and activation of eosinophils [33]. This has been illustrated by several lines of investigation. Exogenous IL-5 administration has been shown to cause eosinophilia in a variety of in vivo models [34]. IL-5-expressing transgenic mice develop lifelong eosinophilia, whereas GM-CSF-expressing transgenic mice show increased numbers of mononuclear cells and neutrophils, but only a minimal increase in the number of eosinophils $[35,36]$. Similar findings emerge from knockout mice. For example, the eosinophil inflammatory response to thioglycollate is not abrogated in $\mathrm{GM}-\mathrm{CSF}^{-/-}$mice [37]. IL- $5^{-/-}$mice, on the other hand, show decreased numbers of circulating eosinophils and fail to mount a normal eosinophilic response to parasitic infections or to ovalbumin challenge $[38,39]$. It should be pointed out that, even in $\mathrm{IL}_{-} 5^{-/-}$mice, a small number of morphologically normal eosinophils remain detectable in the blood. A minor contribution of constitutively expressed IL-3 and GM-CSF to the production of eosinophils can, therefore, not be excluded. However, it is of interest to note that, in the absence of IL-5, local injection of $\mathrm{CC}$ chemokines such as eotaxin cannot induce tissue eosinophilia, even if donor eosinophils have been administered to restore or increase the circulating pool, a procedure which in wild-type animals clearly enhances the tissue response to eotaxin [40].

Inhalation of IL-5 has also been shown to increase the percentage of eosinophils in induced sputum and to augment airway hyperresponsiveness in asthma [7]. Again, expression of IL-5 at the mRNA and protein level is increased in the mucosa of asthmatic airways [41, 42]. Expression of IL-5 mRNA has even been shown to correlate with clinical indices of disease severity. This corresponds with other studies, showing that expression of the IL-5R in bronchial biopsy samples is, in $>90 \%$, restricted to eosinophils, and that expression of the transmembrane form of the IL-5R $\alpha$ chain inversely correlates with the baseline forced expiratory volume in one second (FEV1), whereas expression of the soluble IL-5R $\alpha$ which has IL-5 antagonistic properties, correlates positively with FEV1 [43].

Animal models illustrate that ovalbumin sensitization and exposure in IL- $5^{-/-}$mice does not cause bronchial hyperresponsiveness as opposed to what is found in wild-type mice [39]. In subsequent studies, it was shown that passive transfer of IL-5-secreting CD4+ T-cells from ovalbumin-sensitized wild-type mice to nonsensitized IL $^{-/-}$mice led to airway eosinophilia and an increase in airway responsiveness when these animals were exposed to aerosolized ovalbumin [28]. Similarly, reconstituting IL-5 or IL-5 production, but not IgE, in IL- $4^{-/-}$mice restored all the allergen-induced airway changes [44]. Again, this supports the concept that IL-4 and IL-5 are sequentially involved in the pathogenesis of allergic airway changes, whereas the role of $\operatorname{IgE}$ in the induction of the process seems rather limited. However, it should be noted that experiments using other antigen sources or mouse strains have shown that, although IL-5 is crucial for inducing eosinophil infiltration in the airways, modulation of airway responsiveness can occur independently of IL-5 and airway eosinophilia [30, 45-47]. These observations do not contradict the postulated crucial role of Th2 in this phenomenon. Indeed, other Th2 cytokines can also influence airway responsiveness. For example, CoHn et al. [29] reported, using an ovalbumin $\mathrm{T}$-cell receptor transgenic model, that passive transfer of Th2 from IL- $4^{-/}$ mice can induce airway hyperresponsiveness and pulmonary eosinophil infiltration upon ovalbumin exposure in recipient mice. The passively-transferred T-cells not only produced high levels of IL-5 but also IL-10, and especially IL-13.

\section{Interleukin-13}

IL-13 is also present in increased amounts in asthmatic airways, and has very similar biological 
Table 1.-Biological properties of interleukin (IL)-13 relevant to asthma

Large overlap with IL-4, but human T-cells have no functional IL-13 receptor

Isotype switching of B-cells to immunoglobulin-E synthesis Upregulation of $\mathrm{Fc}_{\varepsilon} \mathrm{R}_{\mathrm{II}}$ expression

Downregulation of production of pro-inflammatory cytokines (TNF- $\alpha$ and IL-1 $\beta$ ), chemokines

(RANTES) and IL-12

Upregulation of expression of VCAM-1, but not of ICAM-1 Increase in eosinophil survival

Chemotaxis and activation of fibroblasts

Stimulation of mucus production

$\mathrm{Fc}_{\varepsilon} \mathrm{R}_{\mathrm{II}}$ : low-affinity immunoglobulin $\mathrm{E}$ receptor; $\mathrm{TNF}-\alpha$ : tumour necrosis factor- $\alpha$; RANTES: regulated on activation, normal T-cell expressed and secreted; VCAM-1: vascular cell adhesion molecule-1; ICAM-1: intercellular adhesion molecule-1.

activities to IL-4 (table 1) [48-50]. This is reflected in the structure of their receptors. The IL-13R consists of the IL-13R $\alpha 1$ or $\alpha 2$ chain, which binds IL-13, and the IL-4R $\alpha$ chain, shared in common with the IL-4R [51]. The signal transduction pathways common to both receptors involve the intracytoplasmatic domain of both chains and are largely STAT-6-dependent. IL-4 can bind to both receptors through IL-4R $\alpha$, and IL-13 binds only to its own receptor. With the exception of T-cells, which do not carry functional IL-13Rs, most cell types respond similarly to IL-4 and IL-13 [52]. Because of this large degree of redundancy, it is difficult to establish with certainty the exact role of IL-4 relative to IL-13 in allergen-induced airway changes, but it would appear that both are functionally active. It has been hypothesized that, although IL-4 is crucial for the initial Th2 development during primary sensitization, IL-13 release might prove more important during secondary antigen exposure [11, 53]. This concept is illustrated in a number of in vivo animal models. As previously explained, the induction of allergen-induced $\mathrm{Th} 2$ development and related phenomena, such as IgE synthesis, airway eosinophilia and airway hyperresponsiveness, is totally abrogated in IL- $4^{-/-}$mice $[15,19]$. The same applies to STAT-6 $6^{-/-}[16,17]$ or IL-4R $\alpha^{-/-}[54]$, but not IL-13 $3^{-/-}$ mice [55]. Administration of neutralizing anti-IL-4 antibodies during sensitization exhibits similar inhibitory effects on Th2 development, thus confirming the importance of IL-4 during the early response to antigen. However, when given only during secondary antigen presentation in already sensitized animals, anti-IL-4 is far less effective in reducing Th2 cytokine production, eosinophil influx and bronchial hyperresponsiveness [19], whereas anti-IL4R maintains therapeutic effects [31]. This confirms in vitro data showing that once T-cells have been committed to a Th2-type phenotype, they become IL-4 independent [56]. At the same time, this suggests that, during secondary antigen exposure, IL-13 plays a more important role than IL-4. In line with these observations, neutralizing endogenously released IL-13 with an IL-13R $\alpha 2 \mathrm{Fc}$ fusion protein during secondary antigen exposure largely inhibits the characteristics of asthma in murine models [54, 57].
Table 2.-Biological properties of interleukin (IL)-9 relevant to asthma

Stimulates proliferation of activated T-cells

Enhances immunoglobulin-E production

Upregulates the $\alpha$ chain of the $\mathrm{Fc}_{\varepsilon} \mathrm{R}_{\mathrm{I}}$ receptor

Enhances IL-5 receptor expression, and differentiation and survival of eosinophils

Promotes proliferation and differentiation of mast cells

Induces CC chemokine expression in lung epithelial cells

\section{Interleukin-9}

Another cytokine derived mainly from Th2, but also from eosinophils, is IL-9 [58]. In vitro data indicate that amongst other features, it stimulates proliferation of activated T-cells, enhances production of IgE from B-cells, promotes proliferation and differentiation of mast cells, upregulates the $\alpha$-chain of the $\mathrm{Fc}_{\varepsilon} \mathrm{R}_{\mathrm{I}}$ receptor and induces $\mathrm{CC}$-chemokine expression in lung epithelial cells (table 2). As such, it could, again, contribute substantially to allergeninduced airway changes. Human data show increased expression of IL-9 in bronchial biopsy samples of asthmatics [59]. In addition, genetic analyses have linked IL-9 to bronchial hyperresponsiveness as a major characteristic of asthma. Animal data are slightly less clear regarding the in vivo role of IL-9. The lung-specific overexpression in transgenic mice has been shown to induce airway hyperresponsiveness in addition to morphological changes that bear similarities to asthma [60]. However, experiments in IL- ${ }^{-/-}$mice indicate that, although IL-9 might play a role in goblet cell hyperplasia and mast cell development, it has little or no effect on eosinophils, T-cell development or immunoglobulin response [61].

The overall message emerging from these and other experiments is that T-cells can alter airway responsiveness in their own right, most probably through production of a cytokine cocktail, the composition of which can vary according to experimental conditions.

\section{Chemokines}

Recruitment of inflammatory cells into the airway mucosa requires, in conjunction with the immunoregulatory activity of $\mathrm{Th} 2$, expression of adhesion molecules on vascular endothelium and chemokine activity. An abundance of chemokines and chemokine receptors has been identified. Based on the number and position of cysteine residues within their amino acid sequence, chemokines can be categorized as $\mathrm{C}$, CC, CXC or CX3C. The global biological activity of the various cytokines within each structurally related group is largely similar. The CXC or $\alpha$-chemokines principally attract neutrophils and have, therefore, mainly been related to acute inflammatory processes. To date, models of allergic inflammation have predominantly focused on the $\mathrm{CC}$ or $\beta$-chemokine family, as these express chemotactic activity towards eosinophils as well as dendritic cells, T-lymphocytes, basophils and monocytes [62]. The precise functional role of each chemokine within this group remains to 
be fully explored. A sequential role for different chemokines in antigen-induced eosinophil recruitment has been suggested [63, 64]. Of particular interest for allergic disorders is the observation that CCR3 receptor expression is limited to eosinophils, basophils and Th2. Several CC chemokines bind to the CCR3 receptor, including RANTES, MCP-3, MCP-4 and the CCR3-specific ligand eotaxin. Increased expression of eotaxin and the CCR3 receptor have been described in bronchial mucosa from asthmatics [65]. Eotaxin expression was shown to correlate with the degree of bronchial hyperresponsiveness. In addition, plasma eotaxin levels have been associated with impaired lung function in a large cohort of asthmatics [66]. These various observations have raised interest in the CCR3 receptor as a potential therapeutic target [67]. Blockade of the CCR3 receptor, using either monoclonal antibodies or modified RANTES proteins such as Met-RANTES or AOP-RANTES, has proven effective in in vivo animal models [63, 68].

\section{Pro-inflammatory cytokines}

Another group of cytokines that needs to be considered are the pro-inflammatory cytokines such as TNF- $\alpha$ and IL-1 $\beta$. The pleiotropic activities of TNF- $\alpha$ include pro-inflammatory effects such as leukocyte recruitment through upregulation of adhesion molecules on vascular endothelial cells and induction of cytokine and chemokine synthesis [69]. In addition, TNF- $\alpha$ also has the potential to stimulate mesenchymal cells such as fibroblasts or smooth muscle cells, and therefore could play an important role in the pathogenesis of airway remodelling [70, 71]. Elevated levels of TNF- $\alpha$ have been detected in sputum, bronchoalveolar lavage fluid and biopsy samples from asthmatics [72-74]. Inhalation of TNF- $\alpha$ causes airway hyperresponsiveness and an increase in sputum neutrophil counts in healthy volunteers [75]. Genetic analysis also links TNF- $\alpha$ to characteristics of asthma as an association has been described between the $-308 \mathrm{TNF}-\alpha$ promoter polymorphism and the degree of bronchial hyperresponsiveness. Allele 2 of the -308 TNF- $\alpha$ polymorphism is characterized by increased releasability of TNF- $\alpha$ in response to various stimuli [76]. Moreover, there is evidence to suggest that TNF- $\alpha$ is an important element in determining the severity of asthma. Sputum and biopsy samples from patients with severe persistent asthma have been shown to contain increased numbers of neutrophils [77-79]. One of the major stimuli for neutrophil recruitment is exposure to endotoxin. The severity of asthma symptoms has been related to the endotoxin content of house dust, rather than to the allergen load in these samples [80]. That the endotoxin-induced effects are largely mediated through the endogenous release of TNF- $\alpha$ is illustrated in in vivo animal models. Exogenous administration of TNF- $\alpha$ was shown to induce airway neutrophilia and hyperresponsiveness, whereas pretreatment with anti-TNF- $\alpha$ antibodies profoundly reduced the endotoxin-induced airway changes [81].

Acute asthma attacks might also be largely TNF- $\alpha$ driven. Increased neutrophilia has been reported in sputum from patients who experience an acute asthma attack [82]. Similarly, bronchoalveolar lavage fluid from subjects who require ventilation due to status asthmaticus contain increased numbers of neutrophils and levels of pro-inflammatory cytokines including TNF- $\alpha[83]$.

\section{Immunomodulatory cytokines}

When evaluating the functional role of cytokines in asthma, it is important to bear in mind that they act within a network of mutually interacting cytokines. Allergic airway inflammation might, therefore, be induced by not only increased expression of Th2 cytokines but also decreased expression of counteracting ones. Interesting cytokines in this respect include IL-12, IL-18, interferon gamma (IFN- $\gamma$ ) and IL-10 (fig. 2).

\section{Interleukin-12, interleukin-18 and interferon gamma}

IL-12 expression has been shown to be reduced in bronchial biopsy samples from asthmatic individuals [49]. IL-12 is produced by antigen-presenting cells and is known to play an important role in Th1/Th2 differentiation during primary antigen presentation [84]. The major antigen presenting cell involved in the process of sensitization to aeroallergens is the dendritic cell present in the airway epithelium. Mucosal dendritic cells demonstrate high antigen uptake but low antigen-presenting capacity. During migration from the airway mucosa to the local lymph nodes, antigen-laden dendritic cells mature, acquiring their full immunostimulatory phenotype. In the lymph nodes, naive T-cells are stimulated and differentiate towards a Th1- or Th2- like phenotype. One of the factors that influence $\mathrm{T}$-cell differentiation is the cytokine composition of the microenvironment, IL-12 having been identified as the necessary cofactor for Th1 development. In vivo animal models have confirmed that exogenous administration of IL-12 during the primary sensitization process, suppresses

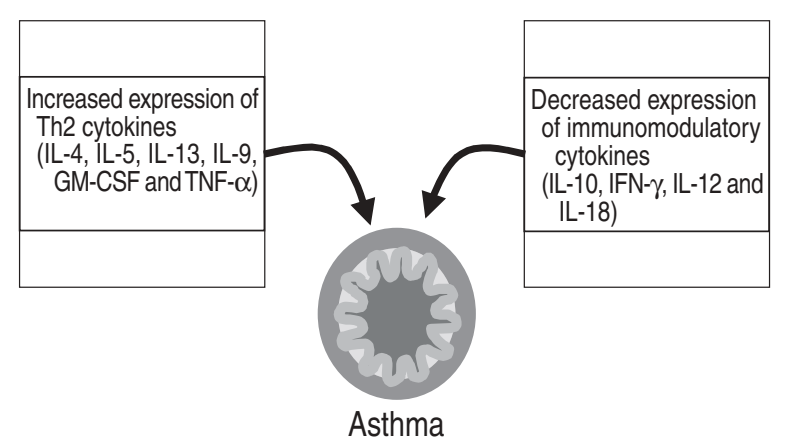

Fig. 2.-The cytokine network involved in the pathogenesis of asthma. Normal airway morphology is shown. Th2: type 2 T-helper cell; IL: interleukin; GM-CSF: granulocyte-macrophage colonystimulating factor; TNF- $\alpha$ : tumour necrosis factor- $\alpha$; IFN- $\gamma$ : interferon gamma. 
allergen-induced Th2 development, favouring Th1 differentiation $[85,86]$.

Interestingly however, even when only administered during secondary antigen exposure, IL-12 retains the capacity to inhibit allergen-induced eosinophilia and airway hyperresponsiveness, despite the persistence of circulating IgE [85]. The precise mechanisms underlying this effect are largely unknown. Fully committed Th2 have been shown to loose their IL-12 responsiveness [87]. Therefore, a reversal of a Th2 towards a Th1 phenotype at this stage is unlikely. IL-12 is known to induce the production of IFN- $\gamma$ and to downregulate IL-5 production, possibly through endogenous release of IL-10 [88, 89]. However, it has been shown that IL-12 retains its immunomodulatory effect, even when given during secondary antigen presentation in IFN$\gamma \mathrm{R}^{-/-}$or IL-10 $0^{-/-}$mice $[90,91]$. The exact mechanisms of these IL-12-mediated effects, therefore, need to be further established.

In view of its biological activities, IL-12 has attracted considerable interest as a potential treatment for allergic disorders. Implementing this approach is, however, hampered by the toxicity of IL-12, which has been noted in human cancer studies [92]. In a recently reported antigen-challenge study in mild asthma, IL-12 was given systemically in incremental doses, as advocated to reduce toxicity. Nevertheless, significant side-effects occurred. In addition, despite a substantial reduction in circulating blood eosinophil count, IL-12 did not influence the antigen-induced early or late asthmatic response [93]. It remains to be further investigated whether topical application or repeated administration of lower doses might prove to be a better therapeutic option. Interesting in this respect is the potential synergistic activity of IL-12 and IL-18. IL-18 is secreted by macrophages and was initially described as IFN- $\gamma$-releasing factor [94]. The absence of endogenous IL-18 ${ }^{-/}$enhances antigen-induced airway eosinophilia [95]. Importantly, IL-12 and IL-18 appear to act synergistically in inducing IFN- $\gamma$ and in inhibiting IL-4-dependent IgE synthesis as well as inhibiting allergen-induced airway hyperresponsiveness [96]. Whether the combination of both cytokines carries less toxic side-effects than equieffective doses of either cytokine given alone needs to be further evaluated.

In in vivo animal models, IFN- $\gamma$ has also been shown to prevent the development of antigen-induced airway eosinophilia and hyperresponsiveness [97-99]. Similarly, IFN- $\gamma \mathrm{R}^{-/-}$mice develop a prolonged airway eosinophilia in response to allergen [100]. To date, however, exogenous administration of IFN- $\gamma$ in humans has proven disappointing. Nebulized IFN- $\gamma$ was reported not to influence baseline FEV1 in mild asthma, and subcutaneous administration of IFN- $\gamma$ did not offer any improvement in steroid-dependent asthmatics [101, 102].

\section{Interleukin-10}

IL-10 is a pleiotropic cytokine that has the potential to downregulate both Th1- and Th2- driven inflammatory processes [103]. It is of interest that IL-10 might also have a beneficial effect on airway remodelling, as it has been shown to reduce collagen type I synthesis and vascular smooth muscle proliferation [104, 105]. The precise functional role of IL-10, however, appears to be somewhat unclear. Whether IL-10 expression is changed in asthma is uncertain, as in some studies reduced and in others increased bronchoalveolar lavage fluid levels were found [106-108]. IL-10, administered exogenously at the time of secondary antigen presentation, reduces antigen-induced airway eosinophilia in animal models [109-111], whereas airway eosinophilia and total serum IgE levels are increased in sensitized IL-10 knockout mice $[112,113]$. However, the effects of IL-10 on airway responsiveness are somewhat more contradictory. In some studies, endogenous production of IL-10 was shown to dampen airway responsiveness [113], whereas others have shown that IL-10 enhances the allergen-induced increase in airway responsiveness, despite the reduction in eosinophil recruitment $[111,112]$.

\section{Conclusion}

Type 2 T-helper lymphocytes are presently considered to be the main orchestrator of the allergic airway inflammation underlying asthma. Functional analysis of the role of cytokines, largely based on in vivo animal models, confirms this hypothesis. T-cells themselves seem to be the main factor in determining the degree of airway inflammation and hyperresponsiveness (fig. 3). It would appear that cytokine production, rather than the influx of eosinophils or production of immunoglobulin-E, is the cause of bronchial hyperresponsiveness. Importantly, biopsy studies clearly illustrate the presence of a complex cytokine network in asthmatic airways. The redundancy of and the mutual interaction between the cytokines within this network needs to be borne in mind when trying to assess the functional role of an

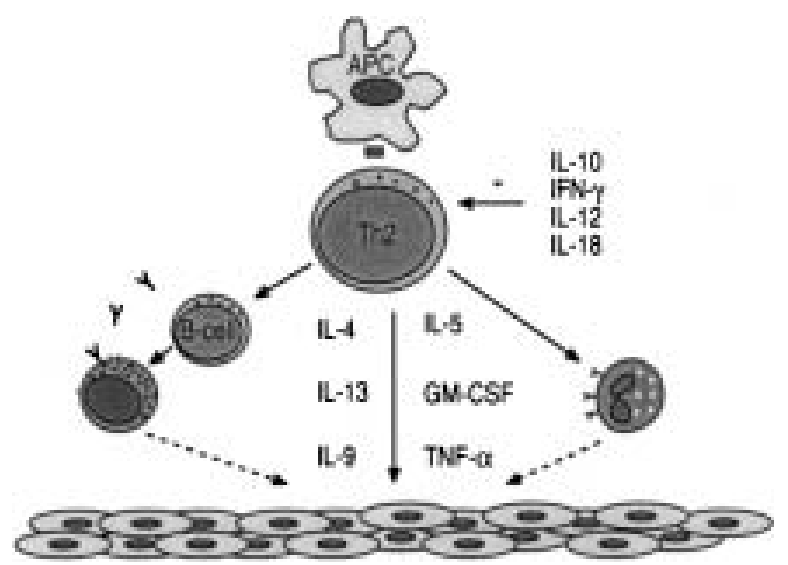

Fig. 3.- The functional role of cytokines involved in the pathogenesis of asthma. APC: antigen-presenting cell; Th2: type 2 T-helper cell; IL: interleukin; IFN- $\gamma$ : interferon gamma; GM-CSF: granulocyte-macrophage colony-stimulating factor; TNF- $\alpha$ : tumour necrosis factor $-\alpha$. 
individual cytokine in a complex disease process such as asthma.

\section{References}

1. Global Strategy for Asthma Management and Prevention. Global Initiative for Asthma. Washington, D.C., National Institutes of Health, National Heart, Lung and Blood Institute, 1995, NIH Publication No. 95-3659.

2. Bousquet J, Jeffery PK, Busse WW, Johnson M, Vignola AM. Asthma. From bronchoconstriction to airways inflammation and remodeling. Am J Respir Crit Care Med 2000; 161: 1720-1745.

3. Chung KF, Barnes PJ. Cytokines in asthma. Thorax 1999; 54: 825-857.

4. Dabbagh K, Takeyama K, Lee HM, Ueki IF, Lausier JA, Nadel JA. IL-4 induces mucin gene expression and goblet cell metaplasia in vitro and in vivo. $J$ Immunol 1999; 162: 6233-6237.

5. Trautmann A, Krohne G, Brocker EB, Klein CE. Human mast cells augment fibroblast proliferation by heterotypic cell-cell adhesion and action of IL-4. J Immunol 1998; 160: 5053-5057.

6. Doucet C, Brouty-Boyé D, Pottin-Clemenceau C, Canonica GW, Jasmin C, Azzarone B. Interleukin (IL) 4 and IL-13 act on human lung fibroblasts. J Clin Invest 1998; 101: 2129-2139.

7. Shi HZ, Xiao CQ, Zhong D, et al. Effect of inhaled interleukin-5 on airway hyperreactivity and eosinophilia in asthmatics. Am J Respir Crit Care Med 1998; 157: 204-209.

8. Humbert M, Durham SR, Ying S, et al. IL-4 and IL-5 mRNA and protein in bronchial biopsies from patients with atopic and nonatopic asthma: evidence against "intrinsic" asthma being a distinct immunopathologic entity. Am J Respir Crit Care Med 1996; 154: 1497-1504.

9. Ying S, Humbert M, Barkans J, et al. Expression of IL-4 and IL-5 mRNA and protein product by CD4+ and CD8+ T cells, eosinophils, and mast cells in bronchial biopsies obtained from atopic and nonatopic (intrinsic) asthmatics. J Immunol 1997; 158: 3539-3544.

10. Bradding $\mathrm{P}$, Roberts JA, Britten KM, et al. Interleukin$4,-5$, and -6 and tumor necrosis factor-alpha in normal and asthmatic airways: evidence for the human mast cell as a source of these cytokines. $\mathrm{Am}$ J Respir Cell Mol Biol 1994; 10: 471-480.

11. de Vries JE. The role of IL-13 and its receptor in allergy and inflammatory responses. J Allergy Clin Immunol 1998; 102: 165-169.

12. Nelms K, Keegan AD, Zamorano J, Ryan JJ, Paul WE. The IL-4 receptor: signaling mechanisms and biologic functions. Annu Rev Immunol 1999; 17: 701-738.

13. Kotsimbos TC, Ghaffar O, Minshall EM, et al. Expression of the IL-4 receptor alpha-subunit is increased in bronchial biopsy specimens from atopic and nonatopic asthmatic subjects. $J$ Allergy Clin Immunol 1998; 102: 859-866.

14. Sandford AJ, Chagani T, Zhu S, et al. Polymorphisms in the IL4, IL4RA, and FCERIB genes and asthma severity. J Allergy Clin Immunol 2000; 106: 135-140.

15. Brusselle GG, Kips JC, Tavernier JH, et al. Attenuation of allergic airway inflammation in IL-4 deficient mice. Clin Exp Allergy 1994; 24: 73-80.
16. Akimoto T, Numata F, Tamura M, et al. Abrogation of bronchial eosinophilic inflammation and airway hyperreactivity in signal transducers and activators of transcription (STAT)6-deficient mice. J Exp Med 1998; 187: 1537-1542.

17. Kuperman D, Schofield B, Wills-Karp M, Grusby MJ. Signal transducer and activator of transcription factor 6 (Stat6)-deficient mice are protected from antigeninduced airway hyperresponsiveness and mucus production. J Exp Med 1998; 187: 939-948.

18. Brusselle G, Kips J, Joos G, Bluethmann H, Pauwels $R$. Allergen-induced airway inflammation and bronchial responsiveness in wild-type and interleukin-4deficient mice. Am J Respir Cell Mol Biol 1995; 12: 254-259.

19. Coyle AJ, Le Gros G, Bertrand C, et al. Interleukin-4 is required for the induction of lung Th2 mucosal immunity. Am J Respir Cell Mol Biol 1995; 13: 54-59.

20. Takeda K, Hamelmann E, Joetham A, et al. Development of eosinophilic airway inflammation and airway hyperresponsiveness in mast cell-deficient mice. $J$ Exp Med 1997; 186: 54-59.

21. Mehlhop PD, van de Rijn M, Goldberg AB, et al. Allergen-induced bronchial hyperreactivity and eosinophilic inflammation occur in the absence of $\operatorname{IgE}$ in a mouse model of asthma. Proc Natl Acad Sci USA 1997; 94: 1344-1349.

22. Korsgren M, Erjefalt JS, Korsgren O, Sundler F, Persson CG. Allergic eosinophil-rich inflammation develops in lungs and airways of B cell-deficient mice. J Exp Med 1997; 185: 885-892.

23. Hamelmann E, Vella AT, Oshiba A, Kappler JW, Marrack P, Gelfand EW. Allergic airway sensitization induces $\mathrm{T}$ cell activation but not airway hyperresponsiveness in B cell-deficient mice. Proc Natl Acad Sci USA 1997; 94: 1350-1355.

24. Hamelmann E, Oshiba A, Schwarze J, et al. Allergenspecific IgE and IL-5 are essential for the development of airway hyperresponsiveness. Am J Respir Cell Mol Biol 1997; 16: 674-682.

25. Coyle AJ, Wagner K, Bertrand C, Tsuyuki S, Bews J, Heusser C. Central role of immunoglobulin (Ig) E in the induction of lung eosinophil infiltration and $\mathrm{T}$ helper 2 cell cytokine production: inhibition by a nonanaphylactogenic anti-IgE antibody. J Exp Med 1996; 183: $1303-1310$.

26. Gavett SH, Chen X, Finkelman F, Wills-Karp M. Depletion of murine CD4+ T lymphocytes prevents antigen-induced airway hyperreactivity and pulmonary eosinophilia. Am J Respir Cell Mol Biol 1994; 10: $587-593$.

27. Li XM, Schofield BH, Wang QF, Kim KH, Huang SK. Induction of pulmonary allergic responses by antigen-specific Th2 cells. J Immunol 1998; 160: 13781384.

28. Hogan SP, Koskinen A, Matthaei KI, Young IG, Foster PS. Interleukin-5-producing CD4+ T cells play a pivotal role in aeroallergen-induced eosinophilia, bronchial hyperreactivity, and lung damage in mice. Am J Respir Crit Care Med 1998; 157: 210-218.

29. Cohn L, Tepper JS, Bottomly K. IL-4-Independent induction of airway hyperresponsiveness by Th2, but not Th1, cells. J Immunol 1998; 161: 3813-3816.

30. Hogan SP, Matthaei KI, Young JM, Koskinen A, Young IG, Foster PS. A novel $\mathrm{T}$ cell-regulated mechanism modulating allergen-induced airways 
hyperreactivity in BALB/c mice independently of IL-4 and IL-5. J Immunol 1998; 161: 1501-1509.

31. Gavett $\mathrm{SH}, \mathrm{O}^{\prime}$ Hearn DJ, Karp CL, et al. Interleukin-4 receptor blockade prevents airway responses induced by antigen challenge in mice. Am J Physiol 1997; 272: L253-L261.

32. Rankin JA, Picarella DE, Geba GP, et al. Phenotypic and physiologic characterization of transgenic mice expressing interleukin 4 in the lung: lymphocytic and eosinophilic inflammation without airway hyperreactivity. Proc Natl Acad Sci USA 1996; 93: 7821-7815.

33. Tavernier J, Plaetinck G, Guisez Y, . The role of IL-5 in the production and function of eosinophils. In: Whetton AD, Gordon, JR, eds. Cell Biochemistry. Vol. 7. Hematopoietic Cell Growth Factors and their Receptors. New York, Plenum Press, 2000; pp. 321361.

34. Iwama T, Nagai H, Suda H, Tsuruoka N, Koda A. Effect of murine recombinant interleukin-5 on the cell population in guinea-pig airways. $\mathrm{Br} J$ Pharmacol 1992; 105: 19-22.

35. Dent LA, Strath M, Mellor AL, Sanderson CJ. Eosinophilia in transgenic mice expressing interleukin 5. J Exp Med 1990; 172: 1425-1431.

36. Johnson GR, Gonda TJ, Metcalf D, Hariharan IK, Cory S. A lethal myeloproliferative syndrome in mice transplanted with bone marrow cells infected with a retrovirus expressing granulocyte-macrophage colony stimulating factor. EMBO J 1989; 8: 441-448.

37. Metcalf D, Robb L, Dunn AR, Mifsud S, Di Rago L. Role of granulocyte-macrophage colony-stimulating factor and granulocyte colony-stimulating factor in the development of an acute neutrophil inflammatory response in mice. Blood 1996; 88: 3755-3764.

38. Kopf M, Brombacher F, Hodgkin PD, et al. IL-5deficient mice have a developmental defect in CD5+ B-1 cells and lack eosinophilia but have normal antibody and cytotoxic $\mathrm{T}$ cell responses. Immunity 1996; 4: 15-24.

39. Foster PS, Hogan SP, Ramsay AJ, Matthaei KI, Young IG. Interleukin 5 deficiency abolishes eosinophilia, airways hyperreactivity, and lung damage in a mouse asthma model. Exp Med 1996; 183: 195-201.

40. Mould AW, Matthaei KI, Young IG, Foster PS. Relationship between interleukin-5 and eotaxin in regulating blood and tissue eosinophilia in mice. J Clin Invest 1997; 99: 1064-1071.

41. Hamid Q, Azzawi, Ying S, et al. Expression of mRNA for interleukin-5 in mucosal bronchial biopsies from asthma. J Clin Invest 1991; 87: 1541-1546.

42. Robinson DS, Ying S, Bentley AM, et al. Relationships among numbers of bronchoalveolar lavage cells expressing messenger ribonucleic acid for cytokines, asthma symptoms, and airway methacholine responsiveness in atopic asthma. J Allergy Clin Immunol 1993; 92: 397-403.

43. Yasruel Z, Humbert M, Kotsimbos TC, et al. Membrane-bound and soluble alpha IL-5 receptor mRNA in the bronchial mucosa of atopic and nonatopic asthmatics. Am J Respir Crit Care Med 1997; 155: 1413-1418.

44. Hamelmann E, Takeda K, Haczku A, et al. Interleukin (IL)-5 but not immunoglobulin $\mathrm{E}$ reconstitutes airway inflammation and airway hyperresponsiveness in IL-4-deficient mice. Am J Respir Cell Mol Biol 2000; 23: $327-334$.

45. Corry DB, Folkesson HG, Warnock ML, et al.
Interleukin 4 , but not interleukin 5 or eosinophils, is required in a murine model of acute airway hyperreactivity. J Exp Med 1996; 183: 109-117.

46. Lefort J, Bachelet CM, Leduc D, Vargaftig BB. Effect of antigen provocation of IL-5 transgenic mice on eosinophil mobilization and bronchial hyperresponsiveness. J Allergy Clin Immunol 1996; 97: 788-799.

47. Coyle AJ, Kohler G, Tsuyuki S, Brombacher F, Kopf M. Eosinophils are not required to induce airway hyperresponsiveness after nematode infection. Eur J Immunol 1998; 28: 2640-2647.

48. Humbert M, Durham SR, Kimmitt P, et al. Elevated expression of messenger ribonucleic acid encoding IL-13 in the bronchial mucosa of atopic and nonatopic subjects with asthma. J Allergy Clin Immunol 1997; 99: 657-665.

49. Naseer T, Minshall EM, Leung DY, et al. Expression of IL-12 and IL-13 mRNA in asthma and their modulation in response to steroid therapy. $\mathrm{Am}$ J Respir Crit Care Med 1997; 155: 845-851.

50. Huang SK, Xiao HQ, Kleine-Tebbe J, et al. IL-13 expression at the sites of allergen challenge in patients with asthma. J Immunol 1995; 155: 2688-2694.

51. Callard RE, Matthews DJ, Hibbert L. IL-4 and IL-13 receptors: are they one and the same?. Immunol Today 1996; 17: 108-110.

52. Graber P, Gretener D, Herren S, et al. The distribution of IL-13 receptor alpha1 expression on B cells, $\mathrm{T}$ cells and monocytes and its regulation by IL-13 and IL-4. Eur J Immunol 1998; 28: 4286-4298.

53. McKenzie GJ, Fallon PG, Emson CL, Grencis RK, McKenzie AN. Simultaneous disruption of interleukin (IL)-4 and IL-13 defines individual roles in T helper cell type 2-mediated responses. $J$ Exp Med 1999; 189: $1565-1572$.

54. Grunig G, Warnock M, Wakil AE, et al. Requirement for IL-13 independently of IL-4 in experimental asthma. Science 1998; 282: 2261-2263.

55. Webb DC, McKenzie AN, Koskinen AM, Yang M, Mattes J, Foster POS. Integrated signals between IL-13, IL-4, and IL-5 regulate airways hyperreactivity. J Immunol 2000; 165: 108-113.

56. Huang H, Hu-Li J, Chen H, Ben-Sasson SZ, Paul WE. IL-4 and IL-13 production in differentiated T helper type 2 cells is not IL-4 dependent. J Immunol 1997; 159: 3731-3738.

57. Wills-Karp M, Luyimbazi J, Xu X, Schofield B, Neben TY, Karp CL, Donaldson DD. Interleukin-13: central mediator of allergic asthma. Science 1998; 282: $2258-2261$.

58. Nicolaides NC, Holroyd KJ, Ewart SL, et al. Interleukin 9: a candidate gene for asthma. Proc Natl Acad Sci USA 1997; 94: 13175-13180.

59. Shimbara A, Christodoulopoulos P, Soussi-Gounni A, et al. IL-9 and its receptor in allergic and nonallergic lung disease: increased expression in asthma. $J$ Allergy Clin Immunol 2000; 105: 108-115.

60. Temann UA, Geba GP, Rankin JA, Flavell RA. Expression of interleukin 9 in the lungs of transgenic mice causes airway inflammation, mast cell hyperplasia, and bronchial hyperresponsiveness. $J$ Exp Med 1998; 188: 1307-1320.

61. Townsend MJ, Fallon PG, Matthews DJ, Smith P, Jolin HE, McKenzie AN. IL-9 deficient mice establish fundamental roles for IL-9 in pulmonary mastocytosis and goblet cell hyperplasia but not $\mathrm{T}$ cell development. Immunity 2000; 13: 573-583. 
62. Baggiolini M. Chemokines and leukocyte traffic. Nature 1998; 392: 565-568.

63. Gonzalo JA, Lloyd CM, Wen D, et al. The coordinated action of $\mathrm{cc}$ chemokines in the lung orchestrates allergic inflammation and airway hyperresponsiveness. J Exp Med 1998; 188: 157-167.

64. Campbell EM, Kunkel SL, Strieter RM, Lukacs NW. Temporal role of chemokines in a murine model of cockroach allergen-induced airway hyperreactivity and eosinophilia. J Immunol 1998; 161: 7047-7053.

65. Ying S, Robinson DS, Meng Q, et al. Enhanced expression of eotaxin and CCR 3 mRNA and protein in atopic asthma. association with airway hyperresponsiveness and predominant co-localization of eotaxin mRNA to bronchial epithelial and endothelial cells. Eur J Immunol 1997; 27: 3507-3516.

66. Nakamura H, Weiss ST, Israel E, Luster AD, Drazen JM, Lilly CM. Eotaxin and impaired lung function in asthma. Am J Respir Crit Care Med 1999; 160: 1952 1956.

67. Nibbs RJ, Salcedo TW, Campbell JD, et al. C-C Chemokine receptor 3 antagonism by the betachemokine macrophage inflammatory protein 4 , a property strongly enhanced by an amino-terminal alanine-methionine swap. J Immunol 2000; 164: 14881497.

68. Elsner J, Petering H, Hochstetter R, et al. The CC chemokine antagonist Met-RANTES inhibits eosinophil effector functions through the chemokine receptors CCR1 and CCR3. Eur J Immunol 1997; 27: 28922898.

69. Hirata N, Kohrogi H, Iwagoe H, et al. Allergen exposure induces the expression of endothelial adhesion molecules in passively sensitized human bronchus: time course and the role of cytokines. $\mathrm{Am}$ J Respir Cell Mol Biol 1998; 18: 12-20.

70. Amrani Y, Panettieri RA Jr, Frossard N, Bronner C. Activation of the TNF Alpha-P55 receptor induces myocyte proliferation and modulates agonist-evoked calcium transients in cultured human tracheal smooth muscle cells. Am J Respir Cell Mol Biol 1996; 15: 5563.

71. Schwingshackl A, Duszyk M, Brown N, Moqbel R. Human eosinophils release matrix metalloproteinase-9 on stimulation with TNF-alpha. $J$ Allergy Clin Immunol 1999; 104: 983-989.

72. Broide DH, Lotz M, Cuomo AJ, Coburn DA, Federman EC, Wasserman SI. Cytokines in symptomatic asthma airways. J Allergy Clin Immunol 1992; 89: 958-967.

73. Keatings VM, Collins PD, Scott DM, Barnes PJ. Differences in interleukin-8 and tumor necrosis factoralpha in induced sputum from patients with chronic obstructive pulmonary disease or asthma. Am J Respir Crit Care Med 1996; 153: 530-534.

74. Ackerman V, Marini M, Vittori E, Bellini A, Vassali G, Mattoli S. Detection of cytokines and their cell sources in bronchial biopsy specimens from asthmatic patients. relationship to atopic status, symptoms, and level of airway hyperresponsiveness. Chest 1994; 105: 687-696.

75. Thomas PS, Yates DH, Barnes PJ. Tumor necrosis factor-alpha increases airway responsiveness and sputum neutrophilia in normal human subjects. $\mathrm{Am}$ J Respir Crit Care Med 1995; 152: 76-80.

76. Li Kam Wa TC, Mansur AH, Britton $\mathrm{J}$, et al. Association between -308 tumour necrosis factor promoter polymorphism and bronchial hyperreactivity in asthma. Clin Exp Allergy 1999; 29: 1204 1208.

77. Wenzel SE, Szefler SJ, Leung DY, Sloan SI, Rex MD, Martin RJ. Bronchoscopic evaluation of severe asthma. persistent inflammation associated with high dose glucocorticoids. Am J Respir Crit Care Med 1997; 156: 737-743.

78. Jatakanon A, Uasuf C, Maziak W, Lim S, Chung KF, Barnes PJ. Neutrophilic inflammation in severe persistent asthma. Am J Respir Crit Care Med 1999; 160: $1532-1539$.

79. Kips JC, on behalf of the ENFUMOSA Study Group. Cellular composition of induced sputum and peripheral blood in severe persistent asthma. Eur Respir J 1999; 14: P2248.

80. Michel O, Kips J, Duchateau J, et al. Severity of asthma is related to endotoxin in house dust. Am J Respir Crit Care Med 1996; 154: 1641-1646.

81. Kips JC, Tavernier J, Pauwels RA. Tumor necrosis factor causes bronchial hyperresponsiveness in rats. Am Rev Respir Dis 1992; 145: 332-336.

82. Ordonez CL, Shaughnessy TE, Matthay MA, Fahy JV. Increased neutrophil numbers and IL-8 levels in airway secretions in acute severe asthma: clinical and biologic significance. Am J Respir Crit Care Med 2000; 161: 1185-1190.

83. Tillie-Leblond I, Pugin J, Marquette $\mathrm{CH}$, et al. Balance between proinflammatory cytokines and their inhibitors in bronchial lavage from patients with status asthmaticus. Am J Respir Crit Care Med 1999; 159: 487-494.

84. Rissoan MC, Soumelis V, Kadowaki N, et al. J. Reciprocal control of $\mathrm{T}$ helper cell and dendritic cell differentiation. Science 1999; 283: 1183-1186.

85. Kips JC, Brusselle GJ, Joos GF, et al. Interleukin-12 inhibits antigen-induced airway hyper-responsiveness in mice. Am J Respir Crit Care Med 1996; 153: 535539.

86. Gavett SH, O'Hearn DJ, Li X, Huang SK, Finkelman FD, Wills-Karp M. Interleukin 12 inhibits antigeninduced airway hyperresponsiveness, inflammation, and Th2 cytokine expression in mice. $J$ Exp Med 1995; 182: 1527-1536.

87. Szabo SJ, Jacobson NG, Dighe AS, Gubler U, Murphy KM. Developmental commitment to the Th2 lineage by extinction of IL-12 signaling. Immunity 1995; 2: 665-675.

88. Lee Y, Fu C, Chiang B. Administration of interleukin12 exerts a therapeutic instead of a long-term preventive effect on mite Der $p$ I allergen-induced animal model of airway inflammation. Immunology 1999; 97: 232240.

89. Wang ZE, Zheng S, Corry DB, et al. Interferon gamma-independent effects of interleukin 12 administered during acute or established infection due to Leishmania major. Proc Natl Acad Sci USA 1994; 91: 12932-12936.

90. Brusselle GG, Kips JC, Peleman RA, et al. Role of IFN-gamma in the inhibition of the allergic airway inflammation caused by IL-12. Am J Respir Cell Mol Biol 1997; 17: 767-771.

91. Tournoy KG, Kips JC, Pauwels RA. The counterbalancing effect of Th2-driven allergic airway inflammation by IL-12 does not require IL-10. J Allergy Clin Immunol 2001

92. Leonard JP, Sherman ML, Fisher GL, et al. Effects of 
single-dose interleukin-12 exposure on interleukin-12associated toxicity and interferon-gamma production. Blood 1997; 90: 2541-2548.

93. Bryan SA, O'Connor B, Matti S, et al. Effects of recombinant human IL-12 on eosinophils, airway hyperresponsiveness and the late asthma response. Lancet 2000; 356: 2149-2153.

94. Okamura H, Tsutsi H, Komatsu T, et al. Cloning of a new cytokine that induces IFN-gamma production by T cells. Nature 1995; 378: 88-91.

95. Kodama $\mathrm{T}$, Matsuyama $\mathrm{T}$, Kuribayashi $\mathrm{K}$, et al. IL-18 deficiency selectively enhances allergen-induced eosinophilia in mice. J Allergy Clin Immunol 2000; 105: 45-53.

96. Hofstra CL, Van Ark I, Hofman G, Kool M, Nijkamp FP, Van Oosterhout AJ. Prevention of Th2-like cell responses by coadministration of IL-12 and IL-18 is associated with inhibition of antigeninduced airway hyperresponsiveness, eosinophilia, and serum IgE levels. J Immunol 1998; 161: 5054 5060.

97. Li XM, Chopra RK, Chou TY, Schofield BH, Wills-Karp M, Huang SK. Mucosal IFN-gamma gene transfer inhibits pulmonary allergic responses in mice. J Immunol 1996; 157: 3216-3219.

98. Lack G, Bradley KL, Hamelmann E, et al. Nebulized IFN-gamma inhibits the development of secondary allergic responses in mice. J Immunol 1996; 157: 14321439 .

99. Iwamoto I, Nakajima H, Endo H, Yoshida S. Interferon gamma regulates antigen-induced eosinophil recruitment into the mouse airways by inhibiting the infiltration of CD4+ T cells. J Exp Med 1993; 177: 573-576.

100. Coyle AJ, Tsuyuki S, Bertrand C, et al. Mice lacking the IFN-gamma receptor have impaired ability to resolve a lung eosinophilic inflammatory response associated with a prolonged capacity of $\mathrm{T}$ cells to exhibit a Th2 cytokine profile. J Immunol 1996; 156: 2680-2685.

101. Boguniewicz M, Martin RJ, Martin D, et al. The effects of nebulized recombinant interferon-gamma in asthmatic airways. J Allergy Clin Immunol 1995; 95: 133-135.

102. Boguniewicz $\mathrm{M}$, Schneider LC, Milgrom $\mathrm{H}$, et al. Treatment of steroid-dependent asthma with recombinant interferon-gamma. Clin Exp Allergy 1993; 23: 785-790.
103. Koulis A, Robinson DS. The anti-inflammatory effects of interleukin-10 in allergic disease. Clin Exp Allergy 2000; 30: 747-750.

104. Selzman CH, McIntyre RC Jr, Shames BD, Whitehill TA, Banerjee A, Harken AH. Interleukin-10 inhibits human vascular smooth muscle proliferation. $\mathrm{J} \mathrm{Mol}$ Cell Cardiol 1998; 30: 889-896.

105. Reitamo S, Remitz A, Tamai K, Uitto J. Interleukin10 modulates type I collagen and matrix metalloprotease gene expression in cultured human skin fibroblasts. J Clin Invest 1994; 94: 2489-2492.

106. Borish L, Aarons A, Rumbyrt J, Cvietusa P, Negri J, Wenzel S. Interleukin-10 regulation in normal subjects and patients with asthma. J Allergy Clin Immunol 1996; 97: 1288-1296.

107. John M, Lim S, Seybold J, et al. Inhaled corticosteroidsincrease interleukin-10 but reduce macrophageinflammatory protein-1alpha, granulocyte-macrophage colony-stimulating factor, and interferon-gamma release from alveolar macrophages in asthma. Am J Respir Crit Care Med 1998; 157: 256-262.

108. Robinson DS, Tsicopoulos A, Meng Q, Durham S, Kay AB, Hamid Q. Increased interleukin-10 messenger rna expression in atopic allergy and asthma. $\mathrm{Am}$ J Respir Cell Mol Biol 1996; 14: 113-117.

109. Zuany-Amorim C, Haile S, Leduc D, et al. Interleukin10 inhibits antigen-induced cellular recruitment into the airways of sensitized mice. $J$ Clin Invest 1995; 95: 2644-2651.

110. Quinn TJ, Taylor S, Wohlford-Lenane CL, Schwartz DA. IL-10 reduces grain dust-induced airway inflammation and airway hyperreactivity. J Appl Physiol 2000; 88: 173-179.

111. van Scott MR, Justice JP, Bradfield JF, Enright E, Sigounas A, Sur S. IL-10 reduces Th2 cytokine production and eosinophilia but augments airway reactivity in allergic mice. Am J Physiol Lung Cell Mol Physiol 2000; 278: L667-L674.

112. Makela MJ, Kanehiro A, Borish L, et al. IL-10 is necessary for the expression of airway hyperresponsiveness but not pulmonary inflammation after allergic sensitization. Proc Natl Acad Sci USA 2000; 97: 60076012.

113. Tournoy KG, Kips JC, Pauwels RA. Endogenous interleukin-10 suppresses allergen-induced airway inflammation and nonspecific airway responsiveness. Clin Exp Allergy 2000; 30: 775-783. 